\title{
Hubungan Kebiasaan Melewatkan Sarapan dan Pemilihan Jajanan dengan Kejadian Wasting di Desa Sembung, Kecamatan Wringinanom, Kabupaten Gresik
}

\section{Association between Skipping Breakfast and Selection of Snack Food with Wasting Incident in Sembung Village, Wringinanom Sub-district, Gresik District}

\author{
Aditya Faisal Rakhman*, Taufiqurrahman ${ }^{1}$
}

\begin{abstract}
ABSTRAK
Latar Belakang: Prevalensi wasting di Indonesia tidak pernah mengalami penurunan yang signifikan selama tahun ke tahun. Kejadian wasting dipengaruhi oleh beberapa faktor seperti kebiasaan sarapan dan pemilihan makanan jajanan yang mampu berkontibusi terhadap tingkat kecukupan energi dan zat gizi anak.

Tujuan: Penelitian ini bertujuan untuk menganalisis hubungan antara kebiasaan melewatkan sarapan dan kebiasan memilih jajanan makanan kejadian wasting pada anak sekolah dasar di pedesaan.

Metode: Penelitian observasional analitik dengan desain case control ini dilakukan di 3 sekolah dasar di Desa Sembung Kecamatan Wringinanom Kabupaten Gresik. Besar sampel penelitian ini adalah 22 sampel untuk masing -masing kelompok yang berasal dari kelas III, IV dan V dan diambil secara simple random sampling. Pengambilan data dilakukan dengan cara wawancara pada anak dengan kuisioner tersktutur. Klasifikasi berdasarkan pada nilai tabel z-score IMT/U WHO-MGRS. Analisis data dilakukan dengan menggunakan uji chi-square $(\alpha=0,05)$

Hasil: Hasil penelitian menunjukkan bahwa $68,2 \%$ responden kelompok kasus, terbiasa melewatkan sarapan sedangkan 27,3\% responden kelompok kontrol terbiasa melewatkan sarapan. 22,7\% responden kelompok kasus terbiasa membeli makanan jajan bernilai gizi tinggi sedangkan $72,7 \%$ responden kelompok kontrol terbiasa membeli makanan jajan bernilai gizi tinggi. Hasil Uji Chi-Square menunjukkan ada hubungan antara kebiasaan sarapan dan pemilihan makanan jajanan dengan kejadian wasting ( $p=0,007$ OR: 5,714) ( $p=0,001$ OR: 9,067).

Kesimpulan: Kebiasaan melewatkan sarapan dan pemilihan makanan jajanan berhubungan dengan kejadian wasting pada anak pedesaan.
\end{abstract}

Kata kunci: wasting, sarapan, pemilihan makanan jajanan

\section{ABSTRACT}

Background: Wasting prevalence in Indonesia is never been decreased for years. Wasting caused by many factors such as skipping breakfast and inappropriate selection of snacks that contribute to children's level of nutritional intake adequacy.

Objectives: The purpose of this research was to analyze correlation between skipping breakfast and selection of snack among elementary school children. 
Method: This was an analytical observational research with case control design conducted in three elementary schools in Sembung Village, Gresik. The sample size was 22 students in each group, which taken using a simple random sampling technique at student of 3rd, 4th and 5th grade. Data was collected by interviewing the respondent with structured questionnaire. Nutritional status was classified with BMI/Age using WHO-MGRS standard. Association among variables were analyzed using Chi-Square test. $(\alpha=0.05)$.

Result: The result showed that $68.2 \%$ respondent from cases used skipping breakfast while $27.3 \%$ respondent from control used to skip breakfast. $22.7 \%$ respondent in cases used to consume high nutritional value snack food while $72.7 \%$ respondent in control used to consume high nutritional value snack food. Chi-Square test showed there was an association between breakfast habits and the selection of snack with wasting ( $p=0.007 ; O R=5.714)$ ( $p=0.001 ; O R=9.067)$.

Conclusion: Skipping breakfast habits and the selection of snack had a correlation with wasting incident in village children.

Keywords: wasting, breakfast, selection of snack

*Koresponden:

rakhmanaditya21@gmail.com

${ }^{1}$ Politeknik Kesehatan Kemenkes Surabaya, Jawa Timur, Indonesia

\section{PENDAHULUAN}

Acute malnutrition atau gizi kurang didefinisikan sebagai berat badan yang sangat rendah menurut tinggi badan dan sangat berkaitan dengan mortalitas pada anak. Gizi kurang merupakan masalah besar yang membutuhkan perhatian khusus terutama di negara berkembang ${ }^{1}$. Food and Agriculture Organization (2009) menyatakan bahwa terdapat 1,02 milyar orang masih kekurangan gizi, atau sekitar $15 \%$ populasi dunia yang sebagian besar berasal dari negara berkembang dan golongan anak-anak adalah yang paling banyak mengalami masalah kekurangan gizi².

Prevalensi wasting di Indonesia memang menunjukan angka yang rendah, pada tahun 2016 mencapai $12,6 \%^{3}$. Menurut Kemenkes (2016) wasting dinyatakan sebagai masalah kesehatan masyarakat jika prevalensinya mencapai $10-\geq 15 \%^{3}$. Meskipun pccrevalensi wasting terbilang rendah, tetapi jumlahnya tidak pernah mengalami penurunan yang signifikan, prevalensi wasting di tahun 2007 mencapai 13,6\%, tahun 2010 menurun menjadi $13,3 \%{ }^{4}$, di tahun 2013 meningkat menjadi $13,5 \%^{5}$ dan tahun 2016 menurun menjadi $12,6 \%^{3}$. Berdasarkan prevalensi wasting, dari 33 provinsi di
Indonesia, 5 provinsi diantaranya masuk kategori moderate (prevalensi $\leq 10 \%$ ), 19 provinsi masuk kategori serius (prevalensi antara 10,1\% - 15\%), dan 9 provinsi masuk kategori kritis (prevalensi $>15 \%{ }^{4}$.

Sarapan mampu memenuhi $15-30 \%$ kebutuhan kebutuhan enegi dan zat gizi harian pada anak. ${ }^{6}$ Pada penelitian Auliana (2012), menjelaskan sebanyak $18,5 \%$ anak di Indonesia masih terbiasa melewatkan sarapan ${ }^{7}$. Penelitian Hardinsyah dan Aries (2012), juga menyebutkan $26,1 \%$ dari 35.000 anak usia sekolah hanya sarapan dengan air minum dan $44,6 \%$ hanya memperoleh asupan energi kurang dari 15\% kebutuhan energi perhari ${ }^{6}$. Kebiasaan melewatkan sarapan juga menjadi salah satu pemicu kebiasaan jajan, penelitian yang dilakukan Mariza dan Kusumastuti (2013), menyatakan bahwa anak yang tidak terbiasa tidak sarapan akan 1,5 kali lebih banyak mengkonsumsi makanan jajanan ${ }^{8}$.

Kejadian wasting pada anak sekolah dasar disebabkan oleh beberapa faktor determinan, salah satunya yaitu kebiasaan jajan. Menurut Pudjiadi (2010) anak sekolah cenderung membeli makanan jajanan dengan kandungan gizi kurang beragam ${ }^{9}$. hal ini mengakibatkan kurangnya asupan zat gizi lain baik makro maupun mikro bagi anak ${ }^{10}$. selain 
itu makanan jajanan anak sekolah yang tidak terjamin nilai gizi dan kebersihanya, berpotensi menyebabkan anak memiliki status gizi yang buruk ${ }^{11}$. Menurut DEPKES RI (2014) lebih dari $25 \%$ anak sekolah dasar menderita anemia gizi ${ }^{12}$. Salah satu penyebab hal tersebut yaitu kebiasaan mengkonsumsi makanan jajanan yang mengenyangkan tetapi bernilai gizi rendah ${ }^{13}$.

Lokasi penelitian merupakan pedesaan yang sebagian besar masyarakatnya bekerja sebagai petani tebu dan pegawai swasta yang memiliki status ekonomi menengah kebawah. Dari hasil pengukuran yang dilakukan kepada anak-anak sekolah dasar sebelumnya, terdapat cukup banyak anak-anak yang memiliki status gizi yang rendah, selain itu juga banyak ditemukan makanan jajanan yang kandungan gizi dan kebersihanya masih di ragukan.

Penelitian ini bertujuan untuk menganalisis hubungan antara kebiasaan melewatkan sarapan dan kebiasan memilih jajanan makanan jajanan terhadap kejadian wasting pada anak sekolah dasar kelas 3-5 di pedesaan.

\section{METODE}

Penelitian ini merupakan penelitian observasional analitik dengan desain case control. Penelitian dilakukan di 3 sekolah dasar di Desa Sembung, kecamatan Wringinanom, Kabupaten Gresik, yaitu di SD 01 Sembung, MI Alhidayah dan MI Daarussalam. Populasi yang digunakan dalam penelitian ini yaitu anak kelas III, IV dan V sekolah dasar di 3 sekolah di Desa Sembung Kecamatan Wringinanom Kabupaten Gresik tahun ajaran 2017-2018. Jumlah sampel yaitu 22 responden kasus dan 22 responden kontrol (1:1) yang didapatkan dari hasil perhitungan rumus Hypothesis test for an odds ratio. Sampel dipilih secara acak dengan metode simple random sampling.

Penelitian dilakukan pada bulan April hingga Mei 2018. Status gizi wasting dinilai secara antropometri menggunakan indikator IMT/U WHO-MGRS. anak dikategorikan wasting jika nilai Z-Score <-3SD - <-2SD dan dikatakan tidak wasting jika nilai Z-Score -2SD - >-2D $\mathrm{D}^{14}$. Berat badan diukur dua kali dengan menggunakan timbangan analog dan tinggi badan diukur dengan microtoise dengan ketelitian 0,1 cm. Data lainya diambil dengan wawancara berdasarkan kuisioner kepada anak. Kebiasaan sarapan dikategorikan menjadi tidak pernah, kadang-kadang (1-2 kali), sering (3-5 kali) dan selalu ( $\geq 6$ kali) selama seminggu dan pemelihan makanan dikategorikan menjadi bernilai gizi tinggi jika mengandung $300 \mathrm{kkal}$ dan 5 gram protein dalam 100 gram makanan jajanan dan bernilai gizi rendah jika mengandung kurang dari 300 kkal dan 5 gram protein dalam 100 gram makanan jajanan ${ }^{15}$. Pemilihan makanan jajanan diukur menggunakan food frequency checklist yang ditanyakan pada anak oleh peneliti.

Uji statistik yang digunakan pada penelitian ini yaitu uji chi-square dengan tingkat kemaknaan 95\% $(\alpha=0,05)$. Penlitian ini telah lolos kaji etik dari komisi etik Fakultas Kesehatan Masyarakat Universitas Airlangga No: 229-KEPK.

\section{HASIL DAN PEMBAHASAN}

Proporsi responden pada penelitian ini didapatkan responden pada kelompok kasus berasal dari 59,1\% SD 01 Sembung, 31,8\% berasal dari MI Alhidayah dan 9,1\% berasar dari MI Daarussalam, sedangkan pada kelompok kontrol 54\% berasal dari SD 01 Sembung, dan 22,7\% masing-masing berasal dari MI Alhidayah dan MI Daarussalam. Hasil penelitian juga mendapatkan pada kelompok kasus, 22,7\% responden berasal dari kelas III, $18,2 \%$ bersal dari kelas IV dan $59,1 \%$ berasal dari kelas $\mathrm{V}$, sedangkan pada kelompok kontrol, 18,2\% berasal dari kelas III, 50\% berasal dari kelas IV dan $31,8 \%$ berasal dari kelas V.

Usia Responden yang menjadi sampel berkisar antara 9-12 tahun. Responden dengan status gizi wasting terbanyak pada kelompok kasus yaitu pada usia 11 tahun dan pada kelompok kontrol yaitu pada usia 10 tahun (36\%, dan 50\%). Jenis kelamin responden pada penelitian ini baik kasus maupun kontrol berjumlah sama, yaitu 14 anak laki-laki $(63,6 \%)$ dan 8 anak perempuan $(36,4 \%)$. 
Tabel 1. Proporsi Responden di 3 Sekolah Dasar di Desa Sembung Kecamatan Wringinanon Kabupaten Gresik

\begin{tabular}{lcccc}
\hline \multirow{2}{*}{$\begin{array}{c}\text { Proporsi } \\
\text { Responden }\end{array}$} & \multicolumn{2}{c}{ Kasus } & \multicolumn{2}{c}{ Kontrol } \\
\cline { 2 - 5 } \multicolumn{1}{c}{$\mathbf{n}$} & $\%$ & $\mathbf{n}$ & $\mathbf{\%}$ \\
\hline Asal Sekolah & & & & \\
SD 01 Sembung & 13 & 59,1 & 12 & 54.5 \\
MI Alhidayah & 7 & 31,8 & 5 & 22.7 \\
MI Daarussalam & 2 & 9,1 & 5 & 22.7 \\
\hline Kelas & & & & \\
III & 5 & 22,7 & 4 & 18,2 \\
IV & 4 & 18,2 & 11 & 50 \\
V & 13 & 59,1 & 7 & 31,8 \\
\hline$\quad$ Total & 22 & 100 & 22 & 100 \\
\hline
\end{tabular}

Tabel 2. Karakteristik Anak di 3 Sekolah Dasar di Desa Sembung Kecamatan Wringinanon Kabupaten Gresik

\begin{tabular}{ccccc}
\hline \multirow{2}{*}{$\begin{array}{c}\text { Karakteristik } \\
\text { Anak }\end{array}$} & \multicolumn{2}{c}{ Kasus } & \multicolumn{2}{c}{ Kontrol } \\
\cline { 2 - 5 } & $\mathbf{n}$ & $\mathbf{\%}$ & $\mathbf{n}$ & $\mathbf{\%}$ \\
\hline Usia & & & & \\
\hline 8 & 3 & 13.6 & 1 & 4,5 \\
9 & 5 & 22,7 & 4 & 18,2 \\
10 & 6 & 27,3 & 11 & 50 \\
11 & 8 & 36,6 & 4 & 18.2 \\
12 & 0 & 0 & 2 & 9.1 \\
\hline Jenis Kelamin & & & & \\
Laki-laki & 14 & 63,6 & 14 & 63,6 \\
Perempuan & 8 & 36,4 & 8 & 36,4 \\
\hline Total & 22 & 100 & 22 & 100 \\
\hline
\end{tabular}

Hasil penelitian mendapatkan kebiasaan sarapan masih belum banyak dilakukan oleh responden kelompok kasus. Sebanyak 50\% responden kelompok kasus mengaku kadangkadang mengkonsumsi sarapan, dan hanya $18,2 \%$ responden yang selalu sarapan. Sedangkan pada kelompok kontrol sebanyak 40,9\% responden mengaku selalu sarapan dan hanya $9,1 \%$ yang mengaku tidak pernah sarapan.

Sarapan mampu memberikan kontribusi bagi tingkat kecukupan energi dan zat gizi anak, jika zat gizi yang dibutuhkan oleh tubuh terpenuhi, maka status gizi anak akan semakin membaik ${ }^{16}$. Menurut Sandercock dkk, (2010) Kebiasaan sarapan berhubungan dengan indeks massa tubuh yang lebih baik pada anak usia sekolah, hasil studi tersebut menyatakan anak-anak yang terbiasa mengkonsumsi sarapan memiliki rata-rata nilai IMT yang lebih rendah dan cenderung tidak akan memiliki status gizi yang lebih ${ }^{17}$. Jika anak terbiasa melewatkan sarapan, maka anak akan kekurangan energi untuk menunjang aktivitasnya, hal ini bisa menyebabkan mudah lelah dan mudah mengantuk ${ }^{18}$.

Tabel 3. Kebiasaan Sarapan Anak di 3 Sekolah Dasar di Desa Sembung Kecamatan Wringinanom, Kabupaten Gresik

\begin{tabular}{lcccc}
\hline \multicolumn{1}{c}{ Kebiasaan } & \multicolumn{2}{c}{ Kasus } & \multicolumn{2}{c}{ Kontrol } \\
\cline { 2 - 5 } \multicolumn{1}{c}{ sarapan } & $\mathbf{n}$ & $\%$ & $\mathbf{n}$ & $\mathbf{\%}$ \\
\hline Tidak Pernah & 4 & 18,2 & 2 & 9,1 \\
Kadang-kadang & 11 & 50 & 4 & 18,2 \\
Sering & 3 & 13,6 & 7 & 31,8 \\
Selalu & 4 & 18,2 & 9 & 40,9 \\
\hline \multicolumn{1}{c}{ Total } & 22 & 100 & 22 & 100 \\
\hline
\end{tabular}

Pemilihan makanan jajanan juga sangat berpengaruh terhadap tingkat konsumsi harian anak. Hasil penelitian menunjukan sebanyak 5 responden (22,7\%) kelompok kasus terbiasa mengkonsumsi makanan jajanan bernilai gizi tinggi, sedangkan pada kelompok kontrol 16 responden (72,7\%) memiliki kebiasaan mengkonsumsi makanan jajanan bernilai gizi tinggi. Sebagian besar waktu anak dihabiskan diluar rumah, dan anak-anak cenderung memilih makanan jajanan yang dijual di sekitarnya daripada pulang ke rumah untuk makan ${ }^{11}$.

Proferawati dkk. (2008) menyatakan permasalahan konsumsi makanan pada anakanak terletak pada pemilihan makanan, anakanak seringkali memilih makanan tertentu yang disukai saja, karakteistik rasa, warna dan bentuk seringkali menjadi faktor penentu anak dalam memilih makanan, adapun faktor gizi seringkali tidak menjadi faktor pertimbangan. ${ }^{19}$ Selain itu makanan jajanan yang tersebar di sekolah masih banyak memiliki nilai gizi rendah. Menurut BPOM (2008) hasil monitoring terhadap makanan jajanan sekolah dasar di Indonesia menunjukan 45,3\% dari 2957 sampel makanan jajanan tidak memenuhi satu atau beberapa persyaratan paramater, baik dari nilai gizi, kemanan pangan maupun higienitasnya. ${ }^{20}$

Pada penelitian ini hubungan kebiasaan sarapan dengan status gizi dikategorikan menjadi dua kategori yaitu kadang-kadang (0- 
2 kali) seminggu dan sering (3-6 kali seminggu). Hasil penelitian menunjukan pada kelompok kasus, sebagian besar responden $(68,2 \%)$ memiliki kebiasaan sarapan kadangkadang, sedangkan hanya sebagian kecil $(27,3 \%)$ responden kelompok kontrol yang memiliki kebiasaan sarapan kadang-kadang.

Tabel 4. Pemilihan Makanan Jajanan anak di 3 Sekolah Dasar di Desa Sembung Kecamatan Wringinanom, Kabupaten Gresik

\begin{tabular}{lcccc}
\hline \multirow{2}{*}{$\begin{array}{c}\text { Pemilihan Makanan } \\
\text { Jajanan }\end{array}$} & \multicolumn{2}{c}{ Kasus } & \multicolumn{2}{c}{ Kontrol } \\
\cline { 2 - 5 } & $\mathbf{n}$ & $\mathbf{( \% )}$ & $\mathbf{n}$ & $\mathbf{( \% )}$ \\
\hline Nilai Gizi Tinggi & 5 & 22.7 & 16 & 72.7 \\
Nilai Gizi Rendah & 17 & 77.3 & 6 & 27.3 \\
\hline Total & 22 & 100 & 22 & 100 \\
\hline
\end{tabular}

Hasil uji statistik menggunakan uji chisquare menunjukan bahwa terdapat hubungan antara kebiasaan melewatkan sarapan dengan kejadian wasting $(P=0,007<$ $0,05)$. Penelitian juga menemukan bahwa anak yang terbiasa melewatkan sarapan 5,714 kali lebih berisiko mengalami wasting (OR: 5,714).

Hasil penelitian ini di dukung penelitian Brata dkk (2016) yang menyatakan adanya hubungan antara kebiasaan sarapan dengan status gizi ${ }^{21}$. Penelitian lain yang mendukung temuan ini yaitu penelitan Ahmad dkk (2011) dalam Saragi dkk (2015) menunjukan 44,6\% responden dari total sampel 105 yang tebiasa melewatkan sarapan memiliki aspek biologis yang kurang baik $^{22}$. Sarapan berkontribusi membentuk kualitas diet pada anak, selain itu juga sarapan memberikan pengaruh positif bagi pemenuhan mikronutrien, peningkatan status gizi dan faktor gaya hidup ${ }^{23}$. Sarapan juga mampu mempengaruhi peningkatan pembelajaran pada anak-anak dalam hal kognitif, perilaku, dan prestasi belajar di sekolah $^{24}$, selain itu sarapan pagi dapat meningkatkan kemampuan fisik sehingga anak yang terbiasa sarapan pagi anak menjadi jarang sakit ${ }^{25}$.

Hasil penelitian menunjukan sebanyak 5 responden $(22,7 \%)$ kelompok kasus memiliki kebiasaan mengkonsumsi makanan jajanan bernilai gizi tinggi, sedangkan pada kelompok kontrol 16 responden $(72,7 \%)$ memiliki kebiasaan mengkonsumsi makanan jajanan bernilai gizi tinggi. Hasil uji statistik menggunakan uji chi-square menunjukan bahwa terdapat hubungan antara pemilihan makanan jajanan dengan kejadian wasting ( $\mathrm{P}$ $=0,001<0,05)$. Hasil penelitian juga menyatakan anak dengan kebiasaan memilih jajanan bernilai gizi rendah 9,067 kali berisiko mengalami wasting (OR: 9,067). Hasil ini didukung oleh penelitian Eka (2009) di SD Hj. Isriati Semarang yang mendapatkan $72,7 \%$ responden memilih makanan jajanan yang nilai gizi dan kebersihanya kurang tejamin ${ }^{26}$. Kebiasaan jajan cenderung menjadi bagian budaya dari satu keluarga dan anak-anak seringkali tidak memperhatikan nilai gizi, kebersihan, dan keamanan bahan pangan dari makanan jajanan yang dikonsumsinya ${ }^{27}$. Kurang tersedianya makanan jajanan bernilai gizi tinggi juga menjadi salah satu faktor yang menyebabkan anak-anak memilih makanan jajanan bernilai gizi rendah, penelitian Wiraningrum dkk (2015) yang dilakukan di Desa Sukopuro Kabupaten Malang menyatakan $85 \%$ makanan jajanan yang ada di sekitar sekolah memiliki energi kurang dari 300 kilokalori dan 55\% makanan jajanan mengandung protein kurang dari 5 gram dalam 100 gram makanan jajanan. ${ }^{15}$ Dalam hal ini peran sekolah sangat penting untuk menyediakan makanan jajanan yang memiliki nilai gizi yang tinggi bagi para siswanya.

Anak sekolah umumnya setiap hari menghabiskan sepertiga waktunya di sekolah, anak cenderung lebih memilih makanan jajanan dibandingkan dengan makanan utama. $^{26}$ Hal ini bisa menjadi masalah apabila makanan jajanan yang dikonsumsinya tidak memiliki kandungan gizi yang tinggi, yang akan berakibat tidak terpenuhinya kebutuhan energi dan zat gizi anak, jika hal ini terus berlanjut, maka akan berpengaruh terhadap status gizi anak. ${ }^{18}$

Sarapan juga memberikan manfaat lainya, seperti meningkatkan konsentrasi dan kemampuan belajar anak, menurut Syahnur (2012) anak yang tebiasa sarapan akan lebih kooperatif, bersemangat dan lebih mudah fokus dalam pelajaran. ${ }^{28}$ Sarapan juga menjadi salah satu aspek yang mempengaruhi perkembangan otak dan mental anak. ${ }^{28,22}$ 
Tabel 5. Hubungan Kebiasaan Melewatkan Sarapan dan Pemilihan Makanan Jajanan dengan Kejadian Wasting Anak di 3 Sekolah Dasar di Desa Sembung Kecamatan Wringinanom, Kabupaten Gresik

\begin{tabular}{|c|c|c|c|c|c|c|}
\hline \multirow{3}{*}{ Variabel } & \multicolumn{4}{|c|}{ Status Gizi } & \multirow{3}{*}{$\mathbf{P}$} & \multirow{3}{*}{ OR } \\
\hline & \multicolumn{2}{|c|}{ Wasting } & \multicolumn{2}{|c|}{ Normal } & & \\
\hline & $\mathbf{n}$ & $\%$ & $\mathbf{n}$ & $\%$ & & \\
\hline \multicolumn{7}{|l|}{ Kebiasaan Sarapan } \\
\hline Kadang-kadang & 15 & 68,2 & 6 & 27,3 & \multirow{2}{*}{0,007} & \multirow{2}{*}{5,714} \\
\hline Sering & 7 & 31,8 & 16 & 72,7 & & \\
\hline \multicolumn{7}{|c|}{ Pemilihan Makanan Jajanan } \\
\hline Nilai Gizi Tinggi & 5 & 22.7 & 16 & 72.7 & \multirow{2}{*}{0,001} & \multirow{2}{*}{9,067} \\
\hline Nilai Gizi Rendah & 17 & 77.3 & 6 & 27.3 & & \\
\hline
\end{tabular}

Pertumbuhan fisik dan mental sangat diperlukan untuk menunjang kehidupan dimasa mendatang bagi seorang anak, hal ini sangat dibutuhkan oleh anak usia sekolah karena pada masa ini kecerdasan mental anak akan dilatih, sehingga mampu membangun dan memperluas keterampilan fisik, psikososial, kognitif dan moral anak sehingga bisa diterima sebagi anggota masyarakat di kemudian hari. ${ }^{29}$

Makanan jajanan mampu menjadi alternatif pemenuhan kebutuhan energi dan zat gizi yang kurang dari konsumsi makan utama, akan tetapi terlalu sering mengkonsumsi makanan jajanan akan mempengaruhi status gizi anak, karena makanan jajanan kebanyakan hanya mengandung karbohidrat saja sehingga anak mudah kenyang dan enggan untuk mengkonsumsi makanan utama. ${ }^{30}$ Anak-anak akan tumbuh sesuai dengan potensi genetik yang dibawanya sejak lahir, akan tetapi hal ini juga dipengaruhi nilai gizi makanan yang dikonsumsinya. Penurunan produktivitas dan prestasi belajar pada anak bisa disebabkan oleh kurangnya cadangan energi dan tingginya lemak pada tubuh anak, yang nantinya mempengaruhi status gizi anak. ${ }^{31}$

\section{KESIMPULAN}

Kebiasaan melewatkan sarapan dan pemilihan makanan jajanan yang salah memiliki peran dalam terjadinya wasting pada anak sekolah dasar. hal ini menjadi dasar bahwa peran orangtua dan sekolah sangat berpengaruh terhadap status gizi anak- anaknya. Sebaiknya orangtua sebisa mungkin menyediakan sarapan dan membiasakan anak untuk sarapan setiap pagi, selain itu orangtua juga harus memberikan edukasi tentang pemilihan makanan jajanan yang baik untuk dikonsumsi oleh anak. Hal ini perlu juga di dukung oleh pihak sekolah yang harus menyediakan makanan jajanan yang bernilai gizi tinggi untuk menghindari pemilihan makanan jajanan yang salah oleh anak.

\section{ACKNOWLEDGEMENT}

Peneliti mengucapkan terimakasih kepada Sekolah Dasar Negeri 01 sembun, MI Alhidayah dan MI Daarussalam yang telah memberikan izin untuk mengadakan penelitian sehingga dapat terlaksananya penelitian ini, peneliti juga mengucapkan terimakasih kepada kepala desa Sembung, responden, guru-guru, serta teman-teman yang telah membantu terlaksananya penelitian ini.

\section{REFERENSI}

1. Global Health Advocate. Undernutrition: the basics. (2014) Available at: http://www.ghadvocates.eu/en/nutritio n/. (Accessed 14th March 2018).

2. Food and Agriculture Organization. More people than ever are victims of hunger. Food Security and Agricultural Mitigation in Developing Countries (2009).

3. Kemenkes RI. Buku Saku Pemantauan Status Gizi dan Indikator Kinerja Gizi 
Tahun 2015. (2016). 17 November 2016

4. Badan Penelitian dan Pengembangan Kesehatan Departemen Kesehatan RI. Riset Kesehatan Dasar. (2010). 1 Desember 2013

5. UNICEF \& Bank, W. T. W. Levels and Trends in Child malnutrition. Midwifery (2014). doi:10.1016/S02666138(96)90067-4

6. Hardinsyah \& Aries, M. Jenis Pangan Sarapan Dan Perannya Dalam Asupan Gizi Harian. J. Gizi dan Pangan 7, 89-96 (2012).

7. Auliana, R. Gizi seimbang dan makanan sehat untuk anak usia dini. 1-12 (2011).

8. Yuni, Y. M., \& Aryu, C. K. Online di : http://ejournal-

s1.undip.ac.id/index.php/jnc Visi Indonesia Sehat 2015 bertujuan untuk. Hub. Antara Kebiasaan Sarapan Dan Kebiasaan Jajan Dengan Status Gizi Anak Sekol. 2, 207-213 (2013).

9. Dini, N.I. Hubungan Konsumsi Makanan Jajanan Terhadap Status Gizi (Kadar Lemak Tubuh Dan IMT/U) Pada Siswa Sekolah Dasar (Studi di Sekolah Dasar Negeri 01 Sumurboto Kota Semarang). J. Kesehat. Masy. 5, 301-306 (2017).

10. Punuh, M. I., Kapantow, N. H. \& Masyarakat, F. K. Hubungan Antara Asupan Energi Dan Zat Gizi Makro Dengan Status Gizi Pada Pelajar Di SMP Negeri 13 Kota. 4, (2015).

11. Sri, E., Suci, T. Gambaran Perilaku Jajan Murid Sekolah Dasar di Jakarta. 1, 2938 (2009).

12. Badan Peneltian dan Pengembangan Kemenkes RI. Riset Kesehatan Dasar. (2013).

13. Sutiari, N. K., Putu, L., Wulandari, L. \& Kedokteran, F. Status anemia gizi besi dan konsumsi zat gizi pada anak usia sekolah di lima panti asuhan di kota denpasar. 1, 35-42 (2012).

14. Kementrian Kesehatan RI. buku-skantropometri-2010.pdf.

15. Wiraningrum, E. A. et al. Pangan Jajanan Anak Sekolah (PJAS), Kecukupan Energi Dan Zat Gizi Anak Sekolah Dasar. J. Inf. Kesehat. Indones. 1, 25-33 (2015).

16. Gibson, S. A. \& Gunn, P. What' s for breakfast? Nutritional implications of breakfast habits: insights from the NDNS. (2011). doi:10.1111/j.14673010.2010.01873.x

17. Sandercock, G. R. H., Voss, C. \& Dye, L. Associations between habitual schoolday breakfast consumption, body mass index, physical activity and cardiorespiratory fitness in English schoolchildren. Eur. J. Clin. Nutr. (2010). doi:10.1038/ejen.2010.145

18. Ali, K. Pangan dan Gizi untuk Kesehatan. Pangan dan Gizi untuk Kesehat. (2003). doi:10.1017/S0007114514003195

19. Proverawati, A., Prawirohartono, P, E. \& Kuntjoro, T. Jenis Kelamin Anak, Pendidikan ibu dan Motivasi Guru Serta Hubunganya Dengan Prefrensi Makanan Sekolah Pada Anak Prasekolah di TK Universitas Muhammadiyah Purwokerto. J. Gizi Klin. Indones. 5, 7883 (2008).

20. BPOM RI. Pengujian Mikrobiologi Pangan. Badan POM RI (2008).

21. Brata A, M., Melani, V. \& Sitoayu, L. Sarapan, Perbedaan Status Gizi Berdasarkan Kebiasaan Siswa, Dan Jajan Serta Tingkat Kecukupannya Pada Selatan, Kelas 4 Dan Di SDN Pejaten Barat 01 Pagi Jakarta. J. Kesehat. Esa Unggul 5, (2016).

22. Saragi, L., Hasanah, O. \& Huda, N. Hubungan Sarapan Pagi Dengan Aspek Bilogis Anak Usia Sekolah. Univ. Riau 2, (2015).

23. Iqbal, F. M., Triastuti, N. J. \& Basuki, S. W. Hubungan Antara Kebiasaan Sarapan Pagi Dan Prestasi Belajar Anak Sekolah Dasar. 1-11 (2015).

24. Neuroscience, H., Adolphus, K., Lawton, C. L., Dye, L. \& Oddy, W. H. The effects of breakfast on behavior and academic performance in children and adolescents. 7, 1-28 (2013).

25. Brown, J. L., Beardslee, W. H. \& Prothrow-Stith, D. Impact of School Breakfast on Children's Health and Learning: An Analysis of the Scientific Research. 1-21 (2008). Available at: http://us.stophunger.org/files/live/sites/stophungerus/files/HungerPdf/Impact of School Breakfast Study_tcm150-212606.pdf. 
26. Eka Putra, A. Gambaran Kebiasaaan Jajan Siswa di Sekolah. Univ. Diponegoro 6, 1-24 (2009).

27. Noviani, K., Fah, E. A. \& Astiti, D. Kebiasaan jajan dan pola makan serta hubungannya dengan status gizi anak usia sekolah di SD Sonosewu Bantul Yogyakarta. J. Gizi Dan Diet. Indones. 4, 97-104 (2016).

28. Syahnur, M., Askar, M., Afrida. Hubungan Kebiasaan Sarapan Pagi dan Status Gizi dengan Prestasi Belajar Anak di SDN 20 Pangkajene Sidrap. STIKES Nani Hasanuddin 2, 42-48 (2013).
29. Potter., Perry. Fundamental of Nursing. Concepts, Process and Practice. Energy (2013).

30. Syafitri, Y., Syarief, H., Baliwati, Y.F. Kebiasaan Jajan Siswa Sekolah Dasar (Studi Kasus di SDN Lawanggintung 01 Kota Bogor ). J. Gizi Dan Pangan. 4, 167-174 (2009).

31. Thompson-McCormick, J. J., Thomas, J. J., Bainivualiku, A., Khan, N. A. \& Becker, A. E. Breakfast skipping as a risk correlate of overweight and obesity in school-going ethnic Fijian adolescent girls. Asia Pac. J. Clin. Nutr. (2010). doi:10.3945/jn.109.114918.144 